\title{
Metabolic Adaptation in Indigenous Siberian Populations
}

\author{
William R. Leonard, ${ }^{1}$ J. Josh Snodgrass, ${ }^{1}$ \\ and Mark V. Sorensen ${ }^{2}$
}

${ }^{1}$ Department of Anthropology, Northwestern University, Evanston, Illinois 60208;
email: w-leonard1@northwestern.edu, j-snodgrass@northwestern.edu
${ }^{2}$ Department of Anthropology, University of North Carolina, Chapel Hill,
North Carolina 27599; email: msorensen@unc.edu

Annu. Rev. Anthropol.

2005. 34:451-71

First published online as a

Review in Advance on

June 28, 2005

The Annual Review of

Anthropology is online at

anthro.annualreviews.org

doi: $10.1146 /$

annurev.anthro.34.081804.120558

Copyright (C) 2005 by

Annual Reviews. All rights

reserved

0084-6570/05/1021-

$0451 \$ 20.00$

\section{Key Words}

basal metabolic rate, total energy expenditure, thyroid function, arctic, lipids

\section{Abstract}

Previous research has suggested that arctic populations have elevated metabolic rates in response to their cold, marginal climate. Recent studies of indigenous Siberian groups have confirmed these earlier findings and have shed light on the mechanisms through which northern populations adapt to their environments. Indigenous Siberians show significant elevations in basal metabolic rate compared with reference values. Total energy expenditure is variable across Siberian groups and is correlated with levels of acculturation. Siberian populations appear to have adapted to cold stress through both short-term acclimatization and genetic adaptations, with thyroid hormones playing an important role in shaping metabolic responses. Elevated metabolic rates also have important consequences for health and may contribute to the low serum lipid levels observed in Siberian groups. Further research is needed to elucidate the underlying mechanisms of metabolic adaptation and their implications for ongoing health changes among indigenous Siberians. 


\section{Contents}

INTRODUCTION............. 452

BACKGROUND 452

ENERGY METABOLISM AND ADAPTION TO CLIMATIC STRESS 454

Basal Metabolic Rate .......... 454

Total Energy Expenditure ....... 458

Dietary Consumption .......... 460

PHYSIOLOGICAL CORRELATES

OF METABOLIC

ADAPTATION .............. 461

Thyroid Function .............. 461

Serum Lipids................ 463

SUMMARY.................. 466

BMR: basal metabolic rate

TEE: total energy expenditure

\section{INTRODUCTION}

Throughout evolutionary history, climatic and ecological forces have exerted strong selective pressure on the human species (Ruff 1991). Temperature (thermal) stress represents one of the most important constraints to which humans have had to adapt. Under conditions of heat stress, selection favors mechanisms for reducing metabolic heat production, whereas in cold environments increased heat production is favored. Roberts (1952, 1978) presented the first systematic evaluation of the link between energy metabolism and environmental temperature in human populations. He found a strong negative correlation between basal metabolic rates (BMR) and mean annual temperature, suggesting that adaptation to regional climatic stressors plays an important role in explaining human variation in metabolic heat production.

Since the early part of the twentieth century, research has suggested that indigenous populations of the arctic have elevated metabolic rates. These early studies found that BMRs of Inuit populations of Alaska and Canada were $25 \%$ to $35 \%$ higher than reference values (Adams \& Covino 1958; Crile \& Quiring 1939; Heinbecker 1928, 1931). However, the results of these early metabolic stud- ies were questioned because of relatively small samples and lack of control for the potentially confounding effects of anxiety, diet, and body composition (Rodahl 1952, Shephard \& Rode 1996). More recent research, with controlled measurement conditions, has largely confirmed the early studies in documenting elevated BMRs among indigenous arctic groups (Galloway et al. 2000, Leonard et al. 2002b, Rode \& Shephard 1995a, Snodgrass et al. 2005). Thus, there is accumulating evidence that native populations of the northern climes show distinctive metabolic adaptations to their cold and marginal environment.

Here we examine the evidence for metabolic adaptations among indigenous Siberian populations. We first provide a brief overview of Siberia and its indigenous peoples. Next we examine energy metabolism among indigenous Siberians and other arctic groups. Specifically, we consider variation in BMR, total energy expenditure (TEE), and daily energy intake. After presenting the evidence for elevated rates of energy metabolism in native Siberians, we explore the physiological correlates of metabolic adaptation. These include (a) variation in thyroid function, a potential mechanism for explaining elevated metabolic rates, and $(b)$ low serum cholesterol and lipid levels, a physiological consequence of increased energy metabolism. Finally, we evaluate the extent to which the variation in metabolic responses in native Siberians and other arctic groups reflects shorter term physiological adjustments (acclimatization) or genetic (evolutionary) adaptations.

\section{BACKGROUND}

Siberia, the vast region of northern Asia extending from the Ural Mountains to the Pacific Ocean, is home to over 30 indigenous populations (Fondahl 1997, Mote 1998). Despite its large geographic dimensions ( $\sim 13$ million square kilometers), Siberia has one of the world's lowest population densities, with a total native population of only about 
1.3 million people. The initial human settlement of most of Siberia occurred relatively recently; although some evidence suggests an early settlement of Arctic Siberia ( 30,000 years ago) (Pitulko et al. 2004), most studies point to a more recent date $(<20,000$ years ago) (Goebel 1999, Mote 1998).

Prolonged contact between Russian and indigenous Siberian populations began in the late sixteenth century as Russian explorers and traders expanded eastward across the Siberian plain in search of animal pelts to procure for the burgeoning European fur market (Forsyth 1992, Slezkine 1994). The initial phase of Russian colonization had profound effects on the lives of native Siberians, in large part through the implementation of a fur tribute system, which increased economic dependence, altered land and resource use, and drastically changed elements of social organization.

Despite the revolution and civil war in Russia and the emergence of the Soviet Union, the period between 1917 and 1929 changed relatively little for most indigenous Siberians (Forsyth 1992). However, the relatively great political, economic, and cultural freedom that indigenous Siberians had experienced in the 1920s was replaced in the 1930s with forced collectivization and industrialization, and shifts in social ideology to "Russify" the native population in order to create a homogeneous ethnic and cultural population (Forsyth 1992, Mote 1998). A key phase of reorganization for Siberia's indigenous people began in the 1930s during collectivization and continued in outlying regions throughout the 1950s; as a result, most indigenous Siberians were forced to abandon past land use patterns and settle in farm sites, fishing villages, and fur-trapping collectives. The Soviet reforms were designed to "enlighten" indigenous people by forcing the abandonment of traditional subsistence practices that were considered primitive; in reality, however, collectivization was an effort to proletarianize the native population and exploit them for the greater good of the Soviet state (Slezkine
1994). As a result, native Siberians experienced major changes during collectivization, including social transformations of an unprecedented magnitude, dietary shifts, alterations to activity patterns, and changes in land use patterns. Beginning in the 1950s, much of Siberia experienced a rapid acceleration in industrialization and urbanization as the result of intensification of food production and expansion of mining industries (Fondahl 1997, Slezkine 1994).

The relatively prosperous days of the 1960s and 1970s largely disappeared by the mid-1980s (Mote 1998). Indigenous Siberians were quite dependent on state wages and welfare subsidies for survival, suffered from high levels of unemployment, and had an extremely low life expectancy (Slezkine 1994). Following the collapse of the Soviet Union in 1991, economic and political changes accelerated and unleashed catastrophic changes for rural Siberians who depended on the government for wages and deliveries of food and essential goods (e.g., petroleum) (Slezkine 1994). Many indigenous Siberians returned to "traditional" subsistence practices in order to meet needs no longer met by the government, although, many of these activities had been transformed during the Russian and Soviet periods (Fondahl 1997, Leonard et al. 2002a, Snodgrass 2004). Today, most rural indigenous Siberians rely on a mixture of subsistence activities (e.g., herding, fishing, and hunting), government wages and pensions, and privatesector salaries.

Since the breakup of the Soviet Union, there has been a marked, well-documented decline in health (e.g., Notzon et al. 2003, Shkolnikov et al. 2001). The effects of the Russian reforms on the health of native Siberians remain largely unknown because nationally representative health studies have not disaggregated data by ethnicity, and only a limited number of studies have examined health among indigenous Siberians during the post-Soviet period.

Siberia has been simultaneously described as "people-poor" but "peoples-rich" to reflect 
the low human population density combined with a diversity of indigenous groups highly variable in culture, ecology, and subsistence economy (Fondahl 1997). In the following, we provide a brief overview of six Siberian populations, four of which we have studied during the post-Soviet period (i.e., Evenki, Ket, Buryat, and Yakut). The geographic locations of the six populations are shown on the map in Figure 1. Mean January temperatures in these locations range from a high of $-22.6^{\circ} \mathrm{C}$ in areas around Lake Baykal to a low of $-40.5^{\circ} \mathrm{C}$ in Yakutia (World Climate 2005).

The Evenki are a Tungusic-speaking population of reindeer herders from the northern regions of the Siberian boreal forest (taiga) (Forsyth 1992). The Evenki population numbered approximately 30,000 at the last major census (Fondahl 1997). Additional information on the study population, as well as on the Evenki in general, can be found in Leonard et al. (1994, 1996, 2002a) and references therein.

The Ket are a central Siberian population structured around fishing. They are extremely small in number, and in the 1989 census numbered less than 1200 (Fondahl 1997). The Ket are apparently a remnant of a considerably larger population, which was centered in the Yenisey valley at the time of initial Russian contact, but which was subsequently decimated by epidemics of infectious disease (Forsyth 1992). The Ket language is unique and, based on available evidence, appears to be unrelated to any known languages.

The Buryat are descendants of Mongol populations that settled in the meadow-steppe region around Lake Baikal at the boundary of the northern forest (Forsyth 1992). The Buryat language belongs to the Mongolic language family. At the time of initial Russian contact, the Buryat population was relatively large and increased substantially during the Russian and Soviet periods; at the last census, the Buryat population numbered over 400,000 (Fondahl 1997, Forsyth 1992). Most rural Buryat today subsist off the products of cattle, which are fed through locally cultivated crops (Humphrey \& Sneath 1999).

The Yakut (Sakha), members of the Turkic language family, number nearly 400,000 and are concentrated in northeastern Siberia (Fondahl 1997, Forsyth 1992, Snodgrass 2004). The Yakut traditionally practiced a complex and locally variable subsistence strategy that was largely dependent upon regional ecological conditions (Tokarev \& Gurvich 1964). In remote parts of the taiga, the Yakut subsisted by hunting and fishing, whereas in the Lena River Valley the primary subsistence activity was transhumant pastoralism (primarily horse and cattle).

The Chukchi are native Siberians of the Chukotka Autonomous Region in the far northeast corner of Siberia. The Chukchi population size is approximately 15,000 (Hannigan 1991). The Chukotka region is largely tundra interspersed with low mountains, with some areas of taiga in the south and west. The Chukchi are both coastal hunters of sea mammals and interior reindeer breeders and herders (Krupnik 1993, Young et al. 1995).

Finally, the Nganasan, a small indigenous population from Taimyr Peninsula of northern Siberia of approximately 1300, were traditionally nomadic herders and hunters of reindeer in the Arctic tundra (Rode et al. 1995, Shephard \& Rode 1996).

\section{ENERGY METABOLISM AND ADAPTION TO CLIMATIC STRESS}

\section{Basal Metabolic Rate}

$\mathrm{BMR}$ (kcal/day) is the minimum energy necessary to maintain an alert, awake state, and is a standard measure used to compare rates of energy expenditure among human populations (Consolazio et al. 1963; McLean \& Tobin 1987). Beginning in the 1920s, anthropologists and comparative physiologists showed that BMRs among high-latitude groups native to North America (Alaska and 


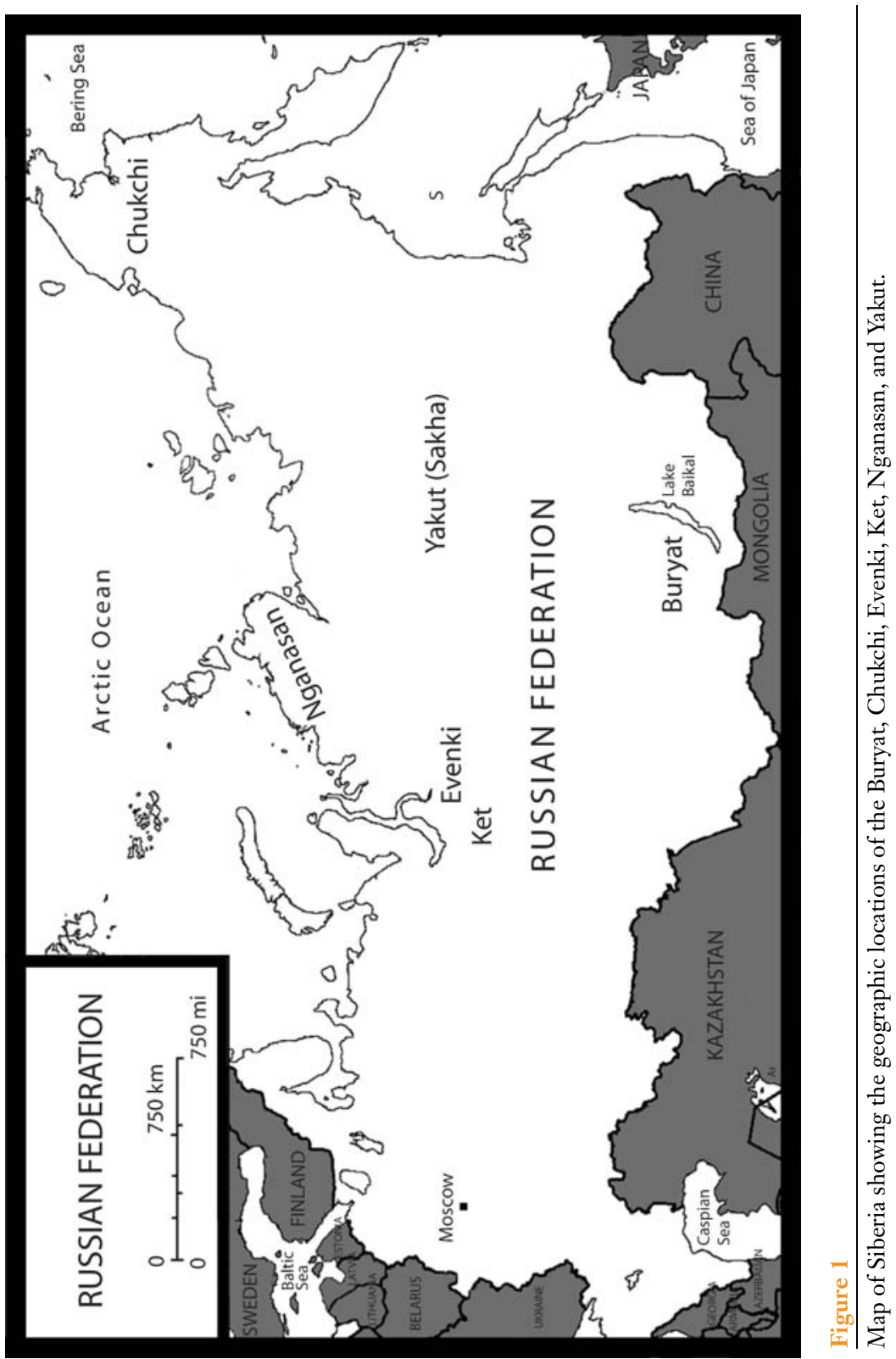


SMR: sleeping metabolic rate
Canada) were elevated compared to lower latitude populations, as well as nonindigenous populations living in the same regions (e.g., Hart et al. 1962, Heinbecker 1928, Milan et al. 1963, Milan \& Evonuk 1967, Rabinowitch \& Smith 1936, Rennie et al. 1962, Rodahl 1952). Most studies were consistent in documenting this metabolic elevation, but some studies found "normal" values (e.g., Heinbecker 1931), and others described differences according to level of acculturation, with elevated values among more traditionally living groups and lower values for groups living under more economically modernized conditions (Hart et al. 1962, Rodahl 1952).

The results of these early studies were questioned because of relatively small samples and lack of control for the potentially confounding effects of anxiety, diet, and body composition. More recent research, with controlled measurement conditions, has been largely consistent with the results of the early studies in documenting elevated BMRs among indigenous circumpolar groups (Leonard et al. 2002b). Rode \& Shephard (1995a), for example, measured BMR among Inuit residents of Igloolik (Nunavut Territory, Canada), and found that this group has greater BMRs than individuals of European descent living in the same communities, as well as compared to predicted elevated values based on lower latitude populations.

Our research in Siberia among 3 indigenous groups (Evenki, Buryat, and Yakut) has documented substantially higher BMRs relative to predicted values derived from European populations and, in some cases, relative to nonindigenous individuals (i.e., Russians) living in the same communities (Galloway et al. 2000, Leonard et al. 2002b, Snodgrass 2004, Snodgrass et al. 2005, Sorensen et al. 1999). A compilation by Leonard et al. (2002b) of BMR measurements from 5 native high-latitude groups from North America and Asia (Inuit, Chippewa, Athapascan, Evenki, and Buryat) found metabolic elevations relative to body mass, fat-free mass, and surface area standards on the order of $+7 \%$ to $+19 \%$ in men and $+3 \%$ to $+17 \%$ in women.

Metabolic elevation among northern populations has been hypothesized to represent a physiological adaptation to chronic and severe cold stress experienced in the circumpolar environment. This is largely based on evidence that BMR and mean annual temperature are strongly inversely related; this association remains even after controlling for population differences in body size (Roberts 1952, 1978). Although most metabolic data have been collected during warmer months, the results of a limited number of multi-season studies support this conclusion through their documentation of highest values during the coldest months (Kashiwazaki 1990; Osiba 1957). Further, a recent study among northern Europeans has also demonstrated seasonal variation in metabolic rate; Danish men and women display a significant seasonal metabolic fluctuation, with the highest SMRs in the winter and the lowest values in the summer (Plasqui et al. 2003). However, not all studies on northern Europeans have consistently shown seasonal metabolic fluctuations (e.g., Haggarty et al. 1994).

Table 1 presents a summary of analyses of a pooled sample BMR data for 108 men and 164 women (18 years and older) from three indigenous Siberian populations (Yakut, Evenki, and Buryat). Relative to the estimates based on the predictive equations of Schofield (1985), measured BMR averaged $5.9 \%$ higher in Siberian men and $4.1 \%$ higher in Siberian women $(\mathrm{P}<0.001)$. The Schofield (1985) norms estimate BMR based on age, sex and body weight, and are endorsed by the World Health Organization (FAO/WHO/UNU 1985) as the standard for assessing population-level energy needs. However, these norms are thought to overestimate BMR in many populations because of sampling bias (e.g., Shetty et al. 1996). As a result, the metabolic deviations estimated relative to the Schofield norms may underestimate the level of hypermetabolism in the Siberian samples. 
Table 1 Measured basal metabolic rate (BMR) in indigenous Siberians and percent deviations from predicted BMR based on estimates from body weight (Schofield 1985) and fat-free mass (FFM; Poehlman \& Toth 1995)

\begin{tabular}{l|l|l|c|c|c|c}
\hline Population & Sex & $\begin{array}{c}\text { Weight } \\
(\mathbf{k g})\end{array}$ & $\begin{array}{c}\text { BMR } \\
\text { (kcal/day) }\end{array}$ & $\begin{array}{c}\text { \% Deviation } \\
\text { (Body Wt } \\
\text { Norms) }\end{array}$ & $\begin{array}{c}\text { \% Deviation } \\
\text { (FFM } \\
\text { Norms) }\end{array}$ & References \\
\hline Evenki & M & 55.3 & 1605 & +5.5 & +14.0 & Leonard et al. (2002b) \\
& $\mathrm{F}$ & 52.0 & 1283 & +2.0 & +13.8 & \\
\hline Buryat & $\mathrm{M}$ & 67.2 & 1758 & +5.0 & +15.6 & Leonard et al. (2002b) \\
& $\mathrm{F}$ & 60.2 & 1379 & +1.6 & +15.8 & \\
\hline Yakut & $\mathrm{M}$ & 66.6 & 1780 & +6.7 & +17.9 & Snodgrass (2004) \\
& $\mathrm{F}$ & 60.4 & 1451 & +6.9 & +23.4 & \\
\hline Combined & $\mathrm{M}$ & 65.1 & 1746 & +5.9 & +16.4 & \\
& $\mathrm{~F}$ & 58.3 & 1388 & +4.1 & +18.8 & \\
\hline
\end{tabular}

To circumvent the problems associated with the Schofield norms, we also compare measured BMRs to those predicted based on lean body mass or FFM (FFM = body weight-fat mass) from equations developed by Poehlman \& Toth (1995). Norms based on FFM have two important advantages over those based on body weight. First, of measures of body size and composition, FFM is the single best predictor of BMR (Elia 1992, Nelson et al. 1992, Sparti et al. 1997). Secondly, norms based on FFM remove the influence of variation in body fatness between the study and reference samples (Poehlman \& Toth 1995, Ravussin \& Bogardus 1989). Measured BMRs were $16.4 \%$ higher than predicted in Siberian men and $18.8 \%$ higher in Siberian women ( $\mathrm{P}<0.001$, for both sexes). Figures $2 a$ and $\boldsymbol{b}$, present BMR versus FFM for Siberian men and women relative to the predicted values based on the Poehlman \& Toth (1995) norms. Note that the best fit regressions for the Siberian men and women are systematically elevated above the lines based on the predicted values. These results suggest that after controlling for variation in body composition, indigenous Siberians show substantial elevations in BMR relative to subjects from temperate climates.
Variation in body composition can also help explain sex differences in metabolic rate among indigenous Siberians. Although BMR is absolutely greater among men than women (1746 versus $1388 \mathrm{kcal} /$ day; $\mathrm{P}<0.001$ ), this is unsurprising given that men in the sample are substantially heavier and leaner than the women. When sex differences were evaluated using FFM, these differences disappear. Although the results of recent studies of Western populations have produced conflicting results, a number of studies (e.g., Klausen et al. 1997) have shown that no significant sex differences exist when controlled for body size and composition.

Body composition differences can also help explain metabolic variation with age in these populations. Research on Western populations has generally documented an agerelated decrease in BMR, although the extent of this decline has probably been overestimated (Henry 2000; Keys et al. 1973; Murray et al. 1996). Among indigenous Siberian adults, age is negatively associated with BMR among men and women; older individuals tend to have relatively lower BMRs. However, when FFM is used to control for the effects of body composition, there are no significant age-related changes in BMR. Thus, changes in body composition with age (i.e., 
PAL: physical activity level increasing levels of fat) play the primary role in explaining changes in BMR with age.

Despite evidence of metabolic elevation among northern groups at a population level, studies also document considerable variation within populations. For example, substantial metabolic variation exists between Evenki communities, even though study participants are similar in anthropometric measures (Galloway et al. 2000). This intrapopulation variation may result from lifestyle differences between the villages; residents of one village are more dependent upon the subsistence economy, have higher physical activity levels, are exposed to more extreme cold stress, and consume a more traditional diet higher in protein than residents of the other community. Intrapopulation variation in metabolism has also been documented among the Canadian Inuit; older, more traditionally living men and women have higher BMRs, and these differences remain even after controlling for differences in body size and composition (Rode \& Shephard 1995a). However, an understanding of this issue remains elusive. Although our research among a large sample of Yakut adults documents substantial intrapopulation variation, this variation is not associated with any measure of lifestyle variation; this, despite extensive data on participation in subsistence activities, diet, socioeconomic status, and material style of life (Snodgrass 2004; Snodgrass et al. 2005).

In sum, indigenous Siberian populations show substantial elevation in BMR relative to standard reference values based on body weight and FFM. These results are similar to those reported for Inuit populations of Alaska and Canada. The mechanisms responsible for promoting elevated metabolic rates in indigenous Siberians and other artic groups are yet to be resolved. However, at least three different pathways have been suggested for explaining the increases: (a) dietary thermogenesis associated with the consumption of high levels of animal protein, (b) acclimatization to climatic stress, and (c) genetic (Darwinian) adaptations to climatic stressors produced by natural selection. Each of these explanations is explored below (see Dietary Consumption, Physiological Correlates of Metabolic Adaptation).

\section{Total Energy Expenditure}

TEE (kcal/day) is the amount of energy that an individual expends over the course of a typical, active day. Compared to BMR, considerably less information is available on TEE and daily activity patterns of Siberians and other indigenous arctic groups. The available data indicate that populations continuing to live largely as subsistence herders or hunters have relatively high levels of activity and energy expenditure for their body size (Godin \& Shephard 1973; Katzmarzyk et al. 1994; Leonard et al. 1997, 2002a). Populations living in more settled villages and towns have more sedentary lifestyles and lower levels of activity and energy expenditure (Leonard 2003).

Daily activity levels of human groups are generally assessed using the PAL index developed by the World Health Organization (FAO/WHO/UNU 1985, James \& Schofield 1990). The PAL is simply the ratio of total energy expenditure to basal energy expenditure, and is calculated as:

$$
\mathrm{PAL}=\mathrm{TEE} / \mathrm{BMR}
$$

The PAL thus provides a measure of the relative amount of energy that a person is expending above their basal needs over the course of a typical day. Table 2 presents the PALs associated with different occupational

Table 2 Physical Activity Levels (PALs) associated with different daily work categories $^{\text {a }}$

\begin{tabular}{l|c|c|c}
\hline \multirow{2}{*}{ Sex } & \multicolumn{3}{|c}{ Daily work level } \\
\cline { 2 - 4 } & Light & Moderate & Heavy \\
\hline Male & 1.55 & 1.78 & 2.10 \\
\hline Female & 1.56 & 1.64 & 1.82 \\
\hline
\end{tabular}

${ }^{a}$ From: FAO/WHO/UNU (1985, p. 78). 
Table 3 Body weight, basal metabolic rate (BMR), total energy expenditure (TEE), and physical activity levels (PAL) of adult men and women of selected circumpolar populations

\begin{tabular}{l|l|c|c|c|c|l}
\hline Population & Sex & $\begin{array}{c}\text { Weight } \\
(\mathbf{k g})\end{array}$ & $\begin{array}{c}\text { BMR } \\
(\mathbf{k c a l} / \mathbf{d})\end{array}$ & $\begin{array}{c}\text { TEE } \\
(\mathbf{k c a l} / \mathbf{d})\end{array}$ & $\begin{array}{c}\text { PAL } \\
\text { (TEE/BMR) }\end{array}$ & \multicolumn{1}{c}{ Reference } \\
\hline Evenki, herders & $\mathrm{M}$ & 61.3 & 1619 & 2805 & 1.74 & Leonard et al. (2002a) \\
& $\mathrm{F}$ & 50.6 & 1363 & 2211 & 1.62 & \\
\hline Evenki, village & $\mathrm{M}$ & 57.5 & 1543 & 2669 & 1.73 & Leonard et al. (2002a) \\
& $\mathrm{F}$ & 51.7 & 1278 & 2101 & 1.67 & \\
\hline Evenki, town & $\mathrm{M}$ & 56.4 & 1622 & 2316 & 1.55 & Leonard (2003) \\
& $\mathrm{F}$ & 63.7 & 1346 & 1664 & 1.23 & \\
\hline Ket, village & $\mathrm{M}$ & 62.3 & 1622 & 2727 & 1.69 & Katzmarzyk et al. (1994) \\
& $\mathrm{F}$ & 50.1 & 1233 & 1860 & 1.51 & \\
\hline Yakut, town & $\mathrm{M}$ & 72.2 & 1848 & 3102 & 1.68 & Snodgrass (2004) \\
& $\mathrm{F}$ & 65.2 & 1533 & 2298 & 1.50 & \\
\hline Inuit hunters & $\mathrm{M}$ & 65.0 & 1728 & 3670 & 2.12 & Godin \& Shephard (1973) \\
\hline Inuit villagers & $\mathrm{M}$ & 65.0 & 1728 & 2500 & 1.45 & Godin \& Shephard (1973) \\
& $\mathrm{F}$ & 55.0 & 1440 & 2400 & 1.67 & \\
\hline
\end{tabular}

work loads for adult men and women (18 years and older) according to WHO guidelines (FAO/WHO/UNU 1985). "Light" daily workloads (PAL $=1.55$ for men, 1.56 for women) are those associated with sedentary, urban lifestyles (e.g., office work). In contrast, heavy work levels (PAL $=2.10$ for men; 1.82 for women) are found among manual laborers and subsistence farmers during harvest periods. Note that at higher levels of work intensity, there are greater gender differences in PALs. This suggests that across human societies, the degree of variation in daily energy expenditure is greater in men than women.

Table 3 presents information on body weight (kg), BMR (kcal/day), TEE (kcal/day), and PALs for adult men and women from selected indigenous circumpolar populationsthe Evenki, Ket, Yakut, and Inuit. For each group, the settlement type is also noted. The most traditionally-living groups are the Evenki of the herding brigades (settlements of 30 to 70 individuals) and the Inuit hunters. "Villages" denote settlements of fewer than 1000 inhabitants, and "towns" are those with more than 1000. Daily activity levels are highest in the more traditionally-living groups. The Inuit hunters studied by Godin \&
Shephard (1973) have high energy demands and PALs consistent with heavy daily work loads ( PAL > 2.1). The Evenki living in both the herding brigades and small villages have expenditure levels consistent with moderate workloads. In contrast, town-dwelling Evenki and Yakut have low activity levels. This is particularly true among the women, who have PALs below the light activity level (PAL = 1.23 for the Evenki, 1.50 for the Yakut).

Figure 3, shows variation in PALs by residence location for the pooled sample of all three Siberian groups $(n=69$ males; 72 females). Among men, acculturation exerts a relatively modest influence on activity patterns. Brigade and village-dwellers have similar PALs $(\sim 1.74)$, and those of town residents are slightly lower (PAL $=$ 1.66). In contrast, woman show much more marked declines in activity levels with urbanization. Woman living in the brigades and villages both have moderate daily activity levels (PALs $=1.62-1.66)$, whereas those living in towns have significantly lower activity levels $(\mathrm{PAL}=1.42 ; \mathrm{P}<0.05)$, barely above the survival level PAL of 1.4. Overall, in the brigades and villages, men and women have similar activity levels; however, in the towns, men have 
Table 4 Comparison of dietary energy, protein and fat intakes: circumpolar populations and U.S.

\begin{tabular}{|c|c|c|c|c|c|c|c|}
\hline Population & Sex & $\begin{array}{c}\text { Energy } \\
\text { (kcal/day) }\end{array}$ & $\begin{array}{l}\text { Protein } \\
\text { (g/day) }\end{array}$ & $\begin{array}{c}\text { Fat } \\
\text { (g/day) }\end{array}$ & $\begin{array}{c}\text { Protein } \\
(\%)\end{array}$ & Fat $(\%)$ & Reference \\
\hline \multicolumn{8}{|l|}{ Siberians: } \\
\hline Buryat & $\begin{array}{l}M \\
\mathrm{~F}\end{array}$ & $\begin{array}{l}2036 \\
1553\end{array}$ & $\begin{array}{l}63.0 \\
51.6\end{array}$ & $\begin{array}{l}86.5 \\
69.9\end{array}$ & $\begin{array}{l}12.4 \\
13.3\end{array}$ & $\begin{array}{l}38.2 \\
40.5\end{array}$ & Leonard et al. (2004) \\
\hline Chukchi & M & 1949 & 163.0 & 93.0 & 26.0 & 32.0 & Nobmann et al. (1991) \\
\hline Evenki & $\begin{array}{l}\mathrm{M} \\
\mathrm{F}\end{array}$ & $\begin{array}{l}2962 \\
2676 \\
\end{array}$ & $\begin{array}{l}120.6 \\
111.9 \\
\end{array}$ & $\begin{array}{l}68.2 \\
69.1 \\
\end{array}$ & $\begin{array}{l}16.4 \\
16.8 \\
\end{array}$ & $\begin{array}{l}20.6 \\
22.7 \\
\end{array}$ & Leonard et al. (2002a) \\
\hline Yakut & $\begin{array}{l}M \\
\mathrm{~F} \\
\end{array}$ & $\begin{array}{l}2352 \\
2343\end{array}$ & $\begin{array}{l}88.1 \\
81.2 \\
\end{array}$ & $\begin{array}{l}89.0 \\
86.7\end{array}$ & $\begin{array}{l}15.0 \\
13.9 \\
\end{array}$ & $\begin{array}{l}34.0 \\
33.3 \\
\end{array}$ & Sorensen (2003) \\
\hline \multicolumn{8}{|c|}{ Other circumpolar populations: } \\
\hline Inuit (Greenland) & M & 1541 & 84.4 & 69.6 & 23.0 & 39.0 & Bang et al. (1980) \\
\hline Inuit (Baffin Island) & $\mathrm{F}$ & 2179 & 136.0 & 86.0 & 26.2 & 35.5 & Kuhnlein (1991) \\
\hline Inuit (Alaska) & $\begin{array}{l}\mathrm{M} \\
\mathrm{F}\end{array}$ & $\begin{array}{l}2754 \\
1945 \\
\end{array}$ & $\begin{array}{r}127.0 \\
90.0 \\
\end{array}$ & $\begin{array}{r}117.0 \\
81.0 \\
\end{array}$ & $\begin{array}{l}19.4 \\
19.4 \\
\end{array}$ & $\begin{array}{l}38.2 \\
37.5 \\
\end{array}$ & Nobmann et al. (1992) \\
\hline Sámi (Finland) & $\begin{array}{l}\mathrm{M} \\
\mathrm{F}\end{array}$ & $\begin{array}{l}2462 \\
1816 \\
\end{array}$ & $\begin{array}{r}123.1 \\
90.8 \\
\end{array}$ & $\begin{array}{r}106.7 \\
78.7 \\
\end{array}$ & $\begin{array}{l}20.0 \\
20.0\end{array}$ & $\begin{array}{l}39.0 \\
39.0 \\
\end{array}$ & $\begin{array}{l}\text { Näyhä et al. (2002) } \\
\text { Haglin (1991) }\end{array}$ \\
\hline \multicolumn{8}{|l|}{ United States } \\
\hline U.S., 1999-2000 & $\begin{array}{l}M \\
\mathrm{~F}\end{array}$ & $\begin{array}{l}2618 \\
1877\end{array}$ & $\begin{array}{r}101.4 \\
70.9\end{array}$ & $\begin{array}{l}95.4 \\
68.4\end{array}$ & $\begin{array}{l}15.5 \\
15.1\end{array}$ & $\begin{array}{l}32.8 \\
32.8\end{array}$ & CDC (2004) \\
\hline
\end{tabular}

significantly higher activity levels than women (1.66 versus $1.42 ; \mathrm{P}<0.05)$. These larger acculturation-related declines in energy expenditure and activity levels among women may help to explain why rates of overweight and obesity are generally higher in Siberian women relative to men $(36 \%$ versus $25 \%$; $\mathrm{P}<0.05$; Leonard et al. 2005).

\section{Dietary Consumption}

To support the elevated energy demands of life in the arctic, indigenous populations consume diets that are rich in energy and animal foods. Table 4 presents dietary intake data for eight indigenous circumpolar populations from around the world and comparative information recently compiled for the United States. Daily energy intakes in the circumpolar groups average $2293 \mathrm{kcal} /$ day in men and $2084 \mathrm{kcal} /$ day in women. Of these groups, detailed analyses of energy balance and dietary adequacy have been conducted only among the Evenki and Yakut. Among the Evenki, we found that during the late summer months, dietary energy intake exceeded energy demands by an average of $18 \%$ in men and $37 \%$ in women (Leonard et al. 2002a). Similarly, intake analyses by Sorensen (2003) and expenditure analyses by Snodgrass (2004) suggest that energy intakes among the Yakut meet or exceed daily needs.

Because these diets are comprised heavily of animal foods, protein intakes are relatively high. Protein accounts for up to $26 \%$ of dietary energy in the more northern indigenous groups (the Chukchi and Baffin Island Inuit), whereas intakes among more southern groups such as the Buryat are more modest $(\sim 13 \%)$. Men consume an average $110 \mathrm{~g} /$ day and women consume about $94 \mathrm{~g} /$ day. When adjusted for body size, these intake levels are approximately double the WHO's minimum recommended level of $0.8 \mathrm{~g} / \mathrm{kg} /$ day (FAO/WHO/UNU 1985). However, they are quite similar to those observed in US men and women, who average 101 and 71 g/day, respectively ( $\sim 15 \%$ of dietary energy). 
Dietary fat intakes in circumpolar men and women average 90 and 79 grams/day, respectively, and comprise approximately 34-36\% of dietary energy. These levels of fat intake are quite moderate in light of their high meat and animal food consumption. In comparison, U.S. men and women consume an average of 95 and $68 \mathrm{~g} /$ day, respectively, with fat contribution about $33 \%$ of dietary energy. The relatively modest fat intakes of circumpolar populations is largely due to the low lipid content of the wild game, fish, and domesticated animals they are consuming. The composition of the fat in these animals is also quite different from that of feedlot animals consumed in Western populations. Relative to feedlot animals, wild and free-ranging domesticated animals have less saturated fat, and higher levels of MUFA and PUFA. Moreover, free-ranging animals and cold-water fish also have high levels of n-3 PUFAs that appear to reduce risks of cardiovascular disease (Cordain et al. 2002).

Earlier studies of diet and metabolism among the Inuit suggested that the high metabolic rates of indigenous northern groups were largely or entirely attributable to the high intakes of animal fat and protein. Rodahl (1952) found that Alaskan Inuit consuming a "traditional" diet had higher BMRs than those consuming a more Western diet. He concluded that elevations in BMR from early Inuit studies were the entirely the product of anxiety and high protein intakes.

Our work indicates that dietary factors are not the entire explanation for increased metabolic rates among northern populations. Indeed, as is evident in Table 4, dietary protein intakes of the Siberian groups that we have studied (Evenki, Buryat and Yakut) are not markedly different from those seen in the U.S. In these groups, elevated BMR cannot be attributed to dietary factors. Additionally, recent laboratory studies indicate that although protein contributes to a metabolic increase following a meal, the effect is transient; thus, dietary protein does not appear to elevate metabolic rate when measured in basal conditions (i.e., at least 12 hours after a meal) (Guyton \& Hall 1996, Reed \& Hill 1996, Soares et al. 1989). Consequently, although high dietary protein intake likely contributed to the extremely high BMRs reported in early Inuit studies, it cannot account for the systematic elevation in metabolic rates evident throughout indigenous populations of the north.

\section{PHYSIOLOGICAL CORRELATES OF METABOLIC ADAPTATION}

\section{Thyroid Function}

Thyroid hormones play a critical role in regulating energy expenditure because they promote oxidative metabolism in most cells (Hadley 1996). The thyroid gland secretes two types of thyroid hormone, $\mathrm{T}_{3}$ (triiodo thyronine) and $\mathrm{T}_{4}$ (thyroxine). Secretion of these hormones is regulated by TSH from the pituitary. The vast majority of the thyroid hormone secreted by the thyroid gland is in the form of thyroxine. Thyroxine can be converted to $T_{3}$ in the peripheral tissues. In the blood, most $T_{3}$ and $T_{4}$ are bound to proteins; however, it is only the free (or unbound) hormones that are biologically active (Hadley 1996, Hardy 1981).

Thyroid hormones increase energy expenditure, in part, by reducing metabolic efficiency at the cellular level. Although the specific molecular mechanisms are not fully resolved, current evidence indicates that thyroid hormones elevate cellular metabolic rates by uncoupling electron transport from the production of ATP within the mitochondria. At the level of the mitochondrion, this "uncoupling" of oxidative phosphorylation results in reduced production of ATP (chemical energy to be used for cellular work) and increased heat production. Recent work suggests that thyroid hormones act partly by influencing transcription of genes coding for proteins that regulate the uncoupling process (e.g., "uncoupling proteins") (Baccari et al. 2004, de Lange et al. 2001).
MUFA:

monounsaturated

fatty acids

PUFA:

polyunsaturated fatty acids

TSH: thyroid stimulating hormone

ATP: adenosine triphosphate 
mtDNA:

mitochondrial DNA
Thyroid function is strongly shaped by climatic factors such as changes in temperature and day length (Salijukov et al. 1992, Smals et al. 1977). Experimental studies have documented seasonal variation in thyroid hormone levels among inhabitants of northern climes. Levine et al. (1995) found increases in total $\mathrm{T}_{3}$ and $\mathrm{T}_{4}$ during the winter among soldiers living in the interior of Alaska. Similarly, Maes et al. (1997) found significant increases in total $\mathrm{T}_{3}$ levels among European men and women during the winter.

Recent work in Russia has examined patterns of seasonal variation in circulating thyroid hormone levels among indigenous and nonindigenous populations. Bojko (1997) studied seasonal variation in $\mathrm{T}_{4}$ levels among Russian men from a mining community in the Svalbard archipelago, one of the northernmost outposts in the world. Thyroxine levels during the winter months were significantly increased over those in the summer. Similar research has been done on indigenous Nenets and nonindigenous Russian men living in the Arkangelsk region of Russia (Tkachev et al. 1991). As in the Svalbard, significant increases in $\mathrm{T}_{4}$ levels were observed during the winter; however, the Nenets showed greater elevations during the winter months, such that their $\mathrm{T}_{4}$ levels were significantly higher than those of the Russians during the November to January period.

Our research in central Siberia has found significantly higher levels of free $T_{4}$ in indigenous Evenki women relative to their nonindigenous Russian counterparts living in the same communities (13.2 versus $11.0 \mathrm{pmol} / \mathrm{l}$; $\mathrm{P}<0.05$ ). Additionally, we found that variation in BMR in Evenki and Russian men and women was positively correlated with variation in free $\mathrm{T}_{4}$ levels (Leonard et al. 1999, 2002b). After adjusting for variation in FFM, the correlations between $\mathrm{BMR}$ and free $\mathrm{T}_{4}$ levels were 0.56 and 0.42 in Evenki men and women, respectively $(\mathrm{P}<0.01)$. Correlations for the Russian men and women were 0.33 and 0.53 , respectively ( $\mathrm{P}<0.05$ for women).
Together, these results suggest that increased thyroid hormone levels are important for promoting elevations in basal metabolism among indigenous Siberians. They also suggest that indigenous groups may display a more pronounced response during the winter. Additional research is needed to examine the magnitude of seasonal variation in BMR among indigenous Siberians. We expect that the larger increases in thyroid hormone levels during the winter months among indigenous Siberians should be associated with greater elevations in BMR.

Recent genetic analyses suggest additional avenues through which thyroid function may influence metabolic adaptation among indigenous arctic populations. Mishmar et al. (2003) and Ruiz-Pesini et al. (2004) examined global variation in mtDNA genes associated with uncoupling of oxidative phosphorylation (e.g., ATP6). These studies found that the mtDNA lineages common to central Asia and Siberia were associated with greater uncoupling and increased metabolic heat production. They hypothesize that natural selection for mutations in mtDNA genes that increased uncoupling of oxidative phosphorylation was critical to the initial expansion of human population into northern climes of Siberia and other parts of northern Eurasia. These findings imply that the metabolic influence of thyroid hormones is greater among indigenous Siberians who have genotypes associated with greater uncoupling in the mitochondria. Further research is needed to explore the influence of mtDNA haplotypes on variation in thyroid hormone levels and BMR. Based on the available evidence we expect that among populations with haplotypes associated with greater uncoupling, increases in metabolic rate can be produced with smaller elevations in thyroid hormone levels.

In sum, thyroid hormones appear to play a central role in regulating metabolic responses among indigenous arctic groups. Short-term changes in thyroid hormone levels are critically important for increasing metabolic rate during the cold winter months. Moreover, 
it also appears that underlying differences in genes responsible for the uncoupling of oxidative phosphorylation in the mitochondria may regulate the influence of thyroid hormones on metabolic rate. These findings suggest that indigenous Siberians may have adapted to cold stress through (a) elevated production and uptake of thyroid hormones and/or (b) increased sensitivity to these hormones. Thus, the interplay between thyroid hormones and the uncoupling of oxidative phosphorylation represents an important axis for both shortterm acclimatization and longer-term genetic adaptation to climatic stress. Further research on gene-environmental interactions in thyroid function and BMR is needed to elucidate the underlying mechanisms for metabolic adaptation.

\section{Serum Lipids}

Cholesterol and other blood lipids (LDL cholesterol and triglycerides) are relatively low in indigenous Siberians and other arctic populations, despite the fact that their diets often include large amounts of animal material. Early research in the first half of the twentieth century found very low cholesterol and triglyceride levels among Inuit hunters of Alaska and Canada (Corcoran \& Rabinowitch 1937; Scott et al. 1958). More recent surveys suggest that the current lipid levels of Inuit populations are now similar to those of urbanized North Americans (Young et al. 1995). These increases in lipid levels are likely the result of the dramatic changes in diet, activity patterns, and body composition that have occurred with acculturation and lifestyle change among the Inuit (Rode \& Shephard 1994; Shephard \& Rode 1996).

In contrast to their North American counterparts, indigenous Siberians continue to have low lipid levels (Leonard et al. 1994; Mosher 2002; Rode \& Shephard 1995b). Tables 5 and 6 compare serum lipid values (TCHOL, LDL, HDL, and triglycerides, $\mathrm{mg} / \mathrm{dl}$ ) of 5 indigenous Siberian groups (the Evenki, Buryat, Yakut, Nganasan, and
Chukchi), to those of the Inuit from the Northwest Territories of Canada and the U.S. fiftieth centile from NHANES III. Total cholesterol levels of all the indigenous Siberian groups are below those of the Inuit and the U.S. median. The Evenki, Buryat, and Nganasan have the lowest cholesterol levels, with males averaging $140-150 \mathrm{mg} / \mathrm{dl}$, and women averaging $150-160 \mathrm{mg} / \mathrm{dl}$. These levels approximate the U.S. fifth centile (see Figures $4 a, b)$. The Yakut have total cholesterol levels that are intermediate, averaging about $170 \mathrm{mg} / \mathrm{dl}$ in men and 180 $\mathrm{mg} / \mathrm{dl}$ in women. The Chukchi have the highest levels among the Siberians, with men and women both averaging about $190 \mathrm{mg} / \mathrm{dl}$. Total cholesterol levels among the Inuit average over $200 \mathrm{mg} / \mathrm{dl}$, and are similar to the U.S. median values (see Figures $4 a, b)$.

LDL cholesterol levels show patterns of variation similar to those observed for total cholesterol. The Evenki, Buryat and Ngansan have the lowest LDL levels, with men's values (average of $80-90 \mathrm{mg} / \mathrm{dl}$ ) approximating the U.S. fifteenth centile, and those for women averaging at the twenty-fifth centile (95$110 \mathrm{mg} / \mathrm{dl})$. Those of the Yakut are intermediate, and fall between the twenty-fifth and fiftieth centiles. The Chukchi and Inuit both have LDL levels that are similar to the U.S. median (120-130 mg/dl).

Triglyceride levels tend to be more similar across all the groups. The Nganasan are markedly different from the other populations, having very low triglyceride levels (averaging $45 \mathrm{mg} / \mathrm{dl}$ in males, and $51 \mathrm{mg} / \mathrm{dl}$ in females) that fall at or below U.S. fifth centile. Triglyceride levels for all the other groups average between 80 and $100 \mathrm{mg} / \mathrm{dl}$, and generally track between the fifteenth and fiftieth centiles.

In contrast to the other lipid measures, HDL cholesterol levels are most favorable among the Inuit and Chukchi. These groups have relatively high HDL levels (>50 mg/dl) which are associated with reduced risk of cardiovascular disease (NIH 2002). The Evenki,
LDL: low density lipoprotein

TCHOL: total cholesterol

HDL: high density lipoprotein

NHANES III: the

Third U.S. National Health and

Nutrition

Examination Survey 
Table 5 Total cholesterol (TCHOL), LDL, HDL, and triglyceride levels (mg/dL) by age group in adult males: indigenous circumpolar populations and U.S. median values

\begin{tabular}{|c|c|c|c|c|c|c|}
\hline Population & Age group & $\begin{array}{l}\text { TCHOL } \\
(\mathrm{mg} / \mathrm{dL})\end{array}$ & $\begin{array}{c}\text { LDL } \\
(\mathrm{mg} / \mathrm{dL})\end{array}$ & $\begin{array}{c}\text { HDL } \\
(\mathrm{mg} / \mathrm{dL})\end{array}$ & $\begin{array}{c}\text { Triglycerides } \\
(\mathrm{mg} / \mathrm{dL})\end{array}$ & References \\
\hline \multirow[t]{5}{*}{ Evenki } & $18-34$ & 134 & 74 & 46 & 81 & Leonard et al. (2002a) \\
\hline & $35-44$ & 155 & 96 & 45 & 86 & \\
\hline & $45-54$ & 146 & 90 & 41 & 95 & \\
\hline & $55-64$ & 147 & 84 & 46 & 86 & \\
\hline & $65 \&$ older & 150 & 107 & 34 & 63 & \\
\hline \multirow[t]{4}{*}{ Buryat } & $18-34$ & 126 & 71 & 37 & 93 & Leonard et al. unpublished \\
\hline & $35-44$ & 143 & 88 & 36 & 94 & \\
\hline & $45-54$ & 169 & 104 & 40 & 123 & \\
\hline & $55-64$ & 135 & 79 & 45 & 54 & \\
\hline \multirow[t]{5}{*}{ Yakut } & $18-34$ & 139 & 82 & 43 & 70 & Sorensen (2003) \\
\hline & $35-44$ & 169 & 111 & 43 & 75 & \\
\hline & $45-54$ & 189 & 122 & 49 & 98 & \\
\hline & $55-64$ & 178 & 118 & 42 & 88 & \\
\hline & $65 \&$ older & 192 & 129 & 42 & 110 & \\
\hline \multirow[t]{4}{*}{ Nganasan $^{\mathrm{a}}$} & $17-19$ & 112 & 69 & 33 & 53 & Rode \& Shephard (1995b) \\
\hline & $20-29$ & 135 & 91 & 33 & 58 & \\
\hline & $30-39$ & 159 & 112 & 37 & 49 & \\
\hline & $40-49$ & 159 & 107 & 33 & 98 & \\
\hline \multirow[t]{4}{*}{ Chukchi } & $18-34$ & 175 & 116 & 53 & 78 & Young et al. (1995) \\
\hline & $35-44$ & 189 & 130 & 53 & 78 & \\
\hline & $45-54$ & 191 & 130 & 54 & 84 & \\
\hline & $55-64$ & 197 & 133 & 58 & 88 & \\
\hline \multirow[t]{5}{*}{ Inuit } & $18-34$ & 171 & 106 & 49 & 83 & Young et al. (1995) \\
\hline & $35-44$ & 225 & 151 & 51 & 118 & \\
\hline & $45-54$ & 213 & 137 & 61 & 81 & \\
\hline & $55-64$ & 215 & 131 & 70 & 67 & \\
\hline & $65 \&$ older & 206 & 129 & 62 & 75 & \\
\hline \multirow[t]{5}{*}{ U.S. median } & $20-34$ & 183 & 119 & 45 & 94 & NIH (2002) \\
\hline & $35-44$ & 205 & 132 & 43 & 126 & \\
\hline & $45-54$ & 214 & 140 & 42 & 135 & \\
\hline & 55-64 & 214 & 135 & 42 & 144 & \\
\hline & $65 \&$ older & 206 & 131 & 43 & 131 & \\
\hline
\end{tabular}

${ }^{\text {a }}$ LDL values for the Nganasan were computed using the Freidewald equation: LDL $=$ TC - HDL - TG/5.

Buryat, and Yakut have more modest HDL levels, averaging $40-50 \mathrm{mg} / \mathrm{dl}$.

Both within and between population variation in lipid levels mirror differences in degree of acculturation and level of isolation. Of the 6 populations discussed above, those with the lowest lipid levels-the Evenki, Buryat, and Nganasan-all lived in small, remote villages and continued to rely heavily on herd- ing and hunting for food. Similarly, with the Evenki, we found that residence location was a strong predictor of total and LDL cholesterol levels, even after controlling for differences in age and body composition (Leonard et al. 1994, 2002a). Individuals living in the herding brigades had significantly lower lipid levels than those living in the villages. These lower lipid levels among the brigade-living 
Table 6 Total cholesterol (TCHOL), LDL, HDL, and triglyceride levels (mg/dL) by age group in adult females: indigenous circumpolar populations and US median values

\begin{tabular}{|c|c|c|c|c|c|c|}
\hline Population & Age group & $\begin{array}{l}\text { TCHOL } \\
\text { (mg/dL) }\end{array}$ & $\begin{array}{c}\text { LDL } \\
(\mathrm{mg} / \mathrm{dL})\end{array}$ & $\begin{array}{c}\text { HDL } \\
(\mathrm{mg} / \mathrm{dL})\end{array}$ & $\begin{array}{c}\text { Triglycerides } \\
(\mathrm{mg} / \mathrm{dL})\end{array}$ & References \\
\hline \multirow{4}{*}{ Evenki } & $18-34$ & 143 & 89 & 44 & 76 & Leonard et al. (2002a) \\
\hline & $35-44$ & 161 & 111 & 40 & 90 & \\
\hline & $45-54$ & 151 & 101 & 41 & 86 & \\
\hline & $55-64$ & 186 & 130 & 47 & 86 & \\
\hline \multirow[t]{5}{*}{ Buryat } & $18-34$ & 136 & 81 & 41 & 70 & Leonard et al. unpublished \\
\hline & $35-44$ & 148 & 91 & 38 & 92 & \\
\hline & $45-54$ & 179 & 114 & 43 & 109 & \\
\hline & $55-64$ & 139 & 83 & 41 & 74 & \\
\hline & $65 \&$ older & 156 & 103 & 36 & 87 & \\
\hline \multirow[t]{5}{*}{ Yakut } & $18-34$ & 160 & 99 & 46 & 75 & Sorensen (2003) \\
\hline & $35-44$ & 165 & 100 & 52 & 67 & \\
\hline & $45-54$ & 186 & 125 & 45 & 81 & \\
\hline & $55-64$ & 194 & 125 & 51 & 87 & \\
\hline & $65 \&$ older & 196 & 127 & 54 & 78 & \\
\hline \multirow[t]{4}{*}{ Nganasan $^{a}$} & $17-19$ & 134 & 90 & 34 & 53 & Rode \& Shephard (1995b) \\
\hline & $20-29$ & 126 & 89 & 33 & 23 & \\
\hline & $30-39$ & 195 & 154 & 27 & 74 & \\
\hline & $40-49$ & 147 & 108 & 33 & 30 & \\
\hline \multirow[t]{4}{*}{ Chukchi } & $18-34$ & 179 & 111 & 60 & 91 & Young et al. (1995) \\
\hline & $35-44$ & 184 & 122 & 60 & 83 & \\
\hline & $45-54$ & 193 & 125 & 60 & 92 & \\
\hline & $55-64$ & 214 & 146 & 65 & 95 & \\
\hline \multirow[t]{5}{*}{ Inuit } & $18-34$ & 181 & 101 & 56 & 97 & Young et al. (1995) \\
\hline & $35-44$ & 211 & 130 & 58 & 120 & \\
\hline & $45-54$ & 218 & 140 & 58 & 102 & \\
\hline & $55-64$ & 208 & 123 & 67 & 91 & \\
\hline & $65 \&$ older & 213 & 134 & 58 & 109 & \\
\hline \multirow[t]{5}{*}{ U.S. median } & $20-34$ & 181 & 109 & 53 & 84 & NIH (2002) \\
\hline & $35-44$ & 192 & 115 & 53 & 93 & \\
\hline & $45-54$ & 212 & 129 & 55 & 114 & \\
\hline & $54-64$ & 229 & 143 & 53 & 135 & \\
\hline & $65 \&$ older & 230 & 144 & 54 & 132 & \\
\hline
\end{tabular}

${ }^{a}$ LDL values for the Nganasan were computed using the Freidewald equation: LDL $=$ TC - HDL - TG/5.

Evenki appear to reflect the joint effects of a more traditional diet and high levels of energy expenditure associated with reindeer herding.

Among the Yakut, however, the opposite trend has been observed-higher total and LDL cholesterol levels among those living in the more rural settlements (Sorensen 2003; Sorensen et al 2005). These differences appear to be influenced by the massive social and economic changes that have occurred in Siberia since the collapse of the Soviet Union. This transition has resulted in increased isolation and marginalization among many rural communities, and has accentuated dietary differences in the rural and urban areas. Sorensen (2003) found that diets of the more rural Yakut contained higher levels of saturated fats, whereas those in the more urban communities, with great market access, contained more 
fruits and vegetables. Additionally, it appears that levels of activity and energy expenditure are lower in the Yakut than in the Evenki. Thus, in the case of the Yakut, consumption of a more traditional diet in the absence of high levels of energy expenditure may contribute to increased serum lipid levels.

Overall, low serum lipid levels continue to characterize indigenous Siberian populations. Elevated levels of energy expenditure associated with $(a)$ increased basal metabolic demands, and (b) high subsistence workloads appear to exert a strong influence on lipid levels among the more-traditionally living Siberian groups. Additionally, the diets of these groups continue to contain large amounts of fish and free-ranging animal (wild or domesticated) that are relatively low in saturated fats and high in concentrations of n-3 fatty acids that appear to protect against cardiovascular disease (Rode et al. 1995).

With acculturation and the shift away from the traditional hunting and herding subsistence regimes, changes in both diet and activity patterns often result in increases in serum lipid levels (Shephard \& Rode 1996). However, this trend is not universal, as evidenced by the recent health and lifestyle changes in post-Soviet Siberia. The collapse of the collective farm infrastructure ("failed modernization") has resulted in increased socioeconomic differentiation in many parts of Siberia, with small, rural communities becoming increasingly isolated and marginalized (Sorensen 2003; Sorensen et al. 2000). In these rural areas, the combination of $(a)$ limited food choices, (b) high psychosocial stress, and $(c)$ an increasingly sedentary lifestyle contributes to higher serum lipid levels and increased risks of cardiovascular disease.

\section{SUMMARY}

Indigenous Siberian populations show substantial elevations in metabolic rates. Basal metabolic rates of Siberians group are about $5 \%$ higher than predicted values based on body mass and 15-20\% higher than those es- timated based on lean body mass. Total energy expenditure is variable across Siberian groups, and is correlated with levels of acculturation. Those groups living in smaller villages with more "traditional" lifestyles have moderate to high daily activity levels. Those living in more urbanized settings have more sedentary lifestyles similar to populations of the industrialized world.

Contrary to earlier research on arctic populations, the elevated BMRs of indigenous Siberians do not appear to be attributable to high dietary protein consumption. Despite the fact that these populations derive a large share of their diet from animal foods, daily protein intakes are not markedly different from those observed among adults of the United States. Rather, elevations in BMR appear to reflect adaptation to severe climatic stress. Thyroid hormones appear to play a central role in regulating metabolic responses among indigenous Siberians. Shortterm changes in thyroid hormone levels are critically important for increasing metabolic rate during the cold winter months. Additionally, it also appears that underlying genetic differences associated with oxidative phosphorylation in the mitochondria may regulate the influence of thyroid hormones on metabolic rate. These findings suggest that indigenous Siberians have adapted to cold stress through both short-term acclimatization and genetic adaptations.

Finally, elevated metabolic rates of indigenous Siberians also have important physiological consequences for health. Siberian groups have relatively low total cholesterol, LDL cholesterol and triglyceride levels, despite consuming diets that are high in energy and animal foods. Serum lipid levels are lowest in the groups that continue live more traditional lifestyles as hunters or herders. With acculturation, reductions in daily activity and energy expenditure and the shift to a Western diet contribute to increases in serum lipid levels and cardiovascular disease risk. However, it appears that the elevated rates of basal metabolism among indigenous 
Siberians may play a role in protecting against more dramatic increases in serum lipid levels with the initial changes in diet and lifestyle associated with urbanization.

Further research is needed to elucidate the underlying mechanisms for metabolic adap- tation to climatic stress among indigenous Siberians and other arctic populations. Such work is critical for understanding the evolutionary origins of these metabolic responses and the potential health consequences of ongoing changes in diet and lifestyle in the arctic.

\section{ACKNOWLEDGMENTS}

We are most grateful to the colleagues we have worked with on this research. We particular thank Drs. M.H. Crawford, L. Tarskaia, L. Osipova, V.A. Spitsyn, V.P. Alekseev, V.G. Krivoshapkin, A.G. Comuzzie, M.J. Mosher, P.T. Katzmarzyk, V.A. Galloway, and E. Ivakine. We also thank Dr. M.L. Robertson for comments and suggestions on earlier drafts of this paper.

\section{LITERATURE CITED}

Adams T, Covino BG. 1958. Racial variations to a standardized cold stress. F. Appl. Physiol. 12:9-12

Baccari GC, Monteforte R, de Lange P, Raucci F, Farina P, Lanni A. 2004. Thyroid hormone affects secretory activity and uncoupling protein-3 expression in rat harderian gland. Endocrinology 145:3338-45

Bang HO, Dyerberg J, Sinclair HM. 1980. The composition of the Eskimo food in northwestern Greenland. Am. F. Clin. Nutr. 33:2657-61

Bojko ER. 1997. Metabolic changes induced by adaptation to circumpolar conditions in Spitsbergen. Int. F. Circumpolar Health 56:134-41

CDC (Cent. Dis. Control). 2004. Trends in intake of energy and macronutrients: United States, 1971-2000. Morbid Mortal Wkly. Rep. 53:80-82

Consolazio CF, Johnson RE, Pecora LJ. 1963. Physiological Measurements of Metabolic Functions in Man. New York: McGraw-Hill

Corcoran ACC, Rabinowitch IM. 1937. A study of blood lipids and blood protein in Canadian eastern arctic Eskimos. Biochemistry 31:343-48

Cordain L, Watkins BA, Florant GL, Kelher M, Rogers L, Li Y. 2002. Fatty acid analysis of wild ruminant tissues: evolutionary implications for reducing diet-related chronic disease. Eur. 7. Clin. Nutr. 56:181-91

Crile GW, Quiring DP. 1939. Indian and Eskimo metabolism. f. Nutr. 18:361-68

de Lange P, Lanni A, Beneduce L, Moreno M, Lombardi A, et al. 2001. Uncoupling protein-3 is a molecular determinant of the regulation of resting metabolic rate by thyroid hormone. Endocrinology 142:3414-20

Elia M. 1992. Energy expenditure in the whole body. In Energy Metabolism: Tissue Determinants and Cellular Corollaries, ed. JM Kinney, HN Tucker, pp. 19-59. New York: Raven

Fondahl G. 1997. Siberia: assimilation and its discontents. In New States, New Politics: Building the Post-Soviet Nations, ed. I Bremmer, R Taras, pp. 190-232. Cambridge: Cambridge Univ. Press

FAO/WHO/UNU (Food Agric. Organ./World Health Organ./United Nations Univ.). 1985. Energy and Protein Requirements: Rep. Ft. FAO/WHO/UNU Expert Consultation. WHO Tech. Rep. Ser: No. 724. Geneva: WHO 
Forsyth J. 1992. A History of the Peoples of Siberia: Russia's Asian Colony 1581-1990. Cambridge: Cambridge Univ. Press

Galloway VA, Leonard WR, Ivakine E. 2000. Basal metabolic adaptation of the Evenki reindeer herders of Central Siberia. Am. F. Hum. Biol. 12:75-87

Godin G, Shephard RJ. 1973. Activity patterns of the Canadian Eskimo. In Polar Human Biology, ed. OG Edholm, EKE Gunderson, pp. 193-215. Chichester: Heinemann Books

Goebel T. 1999. Pleistocene human colonization of Siberia and peopling of the Americas: an ecological approach. Evol. Anthropol. 8:208-27

Guyton AC, Hall JE. 1996. Textbook of Medical Physiology. Philadelphia: Saunders

Hadley ME. 1996. Endocrinology. Upper Saddle River, NJ: Prentice Hall. 4th ed.

Haggarty P, McNeil G, Abu Manneh MK, Davidson L, Milne E, et al. 1994. The influence of exercise on the energy requirements of adult males in the UK. Br. F. Nutr. 72:799-813

Haglin L. 1991. Nutrient intake among Saami people today compared with an old traditional Saami diet. In Circumpolar Health 90, ed. BD Post, pp. 741-46. Winnipeg: Can. Soc. Circumpolar Health

Hannigan J. 1991. Statistics on the Economic and Cultural Development of the Northern Aboriginal People of the USSR (from the period of 1980-1989). Ottawa: Bur. Indian North. Aff.

Hardy RN. 1981. Endocrine Physiology. Baltimore, MD: Univ. Park Press

Hart JS, Sabean HB, Hildes JA, Depogas F, Hammel HT, et al. 1962. Thermal and metabolic responses of coastal Eskimos during night cold. F. Appl. Physiol. 17:953-60

Heinbecker P. 1928. Studies on the metabolism of Eskimos. F. Biol. Chem. 80:461-75

Heinbecker P. 1931. Further studies on the metabolism of Eskimos. F. Biol. Chem. 93:327-36

Henry CJK. 2000. Mechanisms of changes in basal metabolism during ageing. Eur. 7. Clin. Nutr. 54:S77-91

Humphrey C, Sneath D. 1999. The End of Nomadism? Society, State and the Environment in Inner Asia. Durham: Duke Univ. Press

James WPT, Schofield EC. 1990. Human Energy Requirements: A Manual for Planners and Nutritionists. Oxford: Oxford Univ. Press

Kashiwazaki H. 1990. Seasonal fluctuation of BMR in populations not exposed to limitations in food availability: reality or illusion? Eur. F. Clin. Nutr. 44:85-93

Katzmarzyk PT, Leonard WR, Crawford MH, Sukernik RI. 1994. Resting metabolic rate and daily energy expenditure among two Siberian populations. Am. F. Hum. Biol. 6:719-30

Keys A, Taylor HL, Grande F. 1973. Basal metabolism and age of adult men. Metabolism 22:579-89

Klausen B, Toubro S, Astrup A. 1997. Age and sex effects on energy expenditure. Am. F. Clin. Nutr. 65:895-907

Krupnik I. 1993. Arctic Adaptations: Native Whalers and Reindeer Herders of Northern Eurasia. Hanover, NH: Univ. Press N. Engl.

Kuhnlein HV. 1991. Nutrition of the Inuit: a brief overview. In Circumpolar Health 90, ed. BD Post, pp. 728-30. Winnipeg: Can. Soc. Circumpolar Health

Leonard WR. 2003. Measuring human energy expenditure: what have we learned from the flex-heart rate method? Am. F. Hum. Biol. 15:479-89

Leonard WR, Comuzzie AG, Sorensen MV, Mosher MJ, Spitsyn VA. 2004. Leptin, body composition and energy metabolism in the Buryat herders of Siberia. Am. F. Phys. Anthropol. 38(Suppl.):134 (Abstr.)

Leonard WR, Crawford MH, eds. 2002. Human Biology of Pastoral Populations. Cambridge: Cambridge Univ. Press

Leonard WR, Crawford MH, Comuzzie AG, Sukernik RI. 1994. Correlates of low serum lipid levels among the Evenki herders of Siberia. Am. 7. Hum. Biol. 6:329-38 
Leonard WR, Galloway VA, Ivakine E. 1997. Underestimation of daily energy expenditure with the factorial method: implications for anthropological research. Am. F. Phys. Anthropol. 103:443-54

Leonard WR, Galloway VA, Ivakine E, Osipova L, Kazakovtseva M. 1999. Nutrition, thyroid function and basal metabolism of the Evenki of Central Siberia. Int. F. Circumpolar Health 58:281-95

Leonard WR, Galloway VA, Ivakine E, Osipova L, Kazakovtseva M. 2002a. Ecology, health and lifestyle change among the Evenki herders of Siberia. See Leonard \& Crawford 2002, pp. 209-35

Leonard WR, Katzmarzyk PT, Crawford MH. 1996. Energetics and population ecology of Siberian herders. Am. F. Hum. Biol. 8:275-89

Leonard WR, Snodgrass JJ, Sorensen MV, Tarskaia L, Alekseev VP, Krivoshapkin VP. 2005. Health consequences of economic and lifestyle changes among indigenous Siberian populations: the emergence of the metabolic syndrome. Am. F. Phys. Anthropol. 40(Suppl.):137 (Abstr.)

Leonard WR, Sorensen MV, Galloway VA, Spencer GJ, Mosher MJ, et al. 2002b. Climatic influences on basal metabolic rates among circumpolar populations. Am. F. Hum. Biol. 14:609-20

Levine M, Duffy L, Moore DC, Matej LA. 1995. Acclimation of a non-indigenous sub-Arctic population: seasonal variation in thyroid function in interior Alaska. Comp. Biochem. Physiol. A 111:209-14

Maes M, Mommen K, Hendrickx D, Peeters D, D'Hondt P, et al. 1997. Components of biological variation, including seasonality, in blood concentrations of TSH, TT3, FT4, PRL, cortisol and testosterone in healthy volunteers. Clin. Endocrinol. 46:587-98

McLean JA, Tobin G. 1987. Animal and Human Calorimetry. Cambridge: Cambridge Univ. Press

Milan FA, Evonuk E. 1967. Oxygen consumption and body temperatures of Eskimos during sleep. 7. Appl. Physiol. 22:565-67

Milan FA, Hannon JP, Evonuk E. 1963. Temperature regulation of Eskimos, Indians, and Caucasians in a bath calorimeter. F. Appl. Physiol. 18:378-82

Mishmar D, Ruiz-Pesini E, Golik P, Macaulay V, Clarke AG, et al. 2003. Natural se1ection shaped regional mtDNA variation in humans. Proc. Natl. Acad. Sci. USA 100:171-76

Mosher MJ. 2002. The genetic architecture of plasma lipids in the Buyat: an ecogenetic approach. $\mathrm{PhD}$ thesis. Univ. Kans. 175 pp.

Mote VL. 1998. Siberia: Worlds Apart. Boulder, CO: Westview Press

Murray LA, Reilly JJ, Choudhry M, Durnin JVGA. 1996. A longitudinal study of changes in body composition and basal metabolism in physically active elderly men. Eur. F. Appl. Physiol. 72:215-18

NIH (Natl. Inst. Health). 2002. Third Report of the National Cholesterol Education Program (NCEP) Expert Panel on Detection, Evaluation and Treatment of High Cholesterol in Adults (Adult Treatment Panel III): Final Rep. Bethesda, MD: NIH

Näyhä S, Luoma P, Lehtinen S, Lehtimäki T, Mosher MJ, Leppäluoto J. 2002. Disease patterns in Sámi and Finnish populations: an update. See Leonard \& Crawford 2002, pp. 236-50

Nelson KM, Weinsier RL, Long CL, Schutz Y. 1992. Predictions of resting energy expenditure from fat-free mass and fat mass. Am. 7. Clin. Nutr. 56:848-56

Nobmann ED, Byers T, Lanier AP, Hankin JH, Jackson MY. 1992. The diet of Alaska native adults: 1987-1988. Am. F. Clin. Nutr. 55:1024-32 
Nobmann ED, Mamieeva FR, Rodigina TA. 1991. A preliminary comparison of the nutrient intakes of the Siberian Chukotka and Alaska native. In Circumpolar Health 90, ed. BD Post, pp. 752-55. Winnipeg: Can. Soc. Circumpolar Health

Notzon FC, Komarov YM, Ermakov SP, Hanson MB, Albertorio J. 2003. Vital and health statistics: Russian Federation and United States, selected years 1985-2000 with an overview of Russian mortality in the 1990s. Vital Health Stat. 5:1-55

Osiba S. 1957. The seasonal variation of basal metabolism and activity of thyroid gland in man. 7pn. 7. Physiol. 7:355-65

Pitulko VV, Nikolsky PA, Girya EY, Basilyan AE, Tumskoy VE, et al. 2004. The Yana RHS site: humans in the Arctic before the last glacial maximum. Science 303:52-56

Plasqui G, Kester ADM, Westerterp KR. 2003. Seasonal variation in sleeping metabolic rate, thyroid activity, and leptin. Am. F. Physiol. Endocrinol. Metab. 285:E338-43

Poehlman ET, Toth MJ. 1995. Mathematical ratios lead to spurious conclusions regarding ageand sex-related differences in resting metabolic rate. Am. F. Clin. Nutr. 61:482-85

Rabinowitch IM, Smith FC. 1936. Metabolic studies of Eskimos in the Canadian eastern Arctic. 7. Nutr. 12:337-56

Ravussin E, Bogardus C. 1989. Relationship of genetics, age and physical fitness to daily energy expenditure and fuel utilization. Am. F. Clin. Nutr. 49:968-75

Reed GW, Hill JO. 1996. Measuring the thermic effect of food. Am. F. Clin. Nutr. 63:164-69

Rennie DW, Covino BG, Blair MR, Rodahl K. 1962. Physical regulation of temperature in Eskimos. 7. Appl. Physiol. 17:326-32

Roberts DF. 1952. Basal metabolism, race, and climate. F. R. Anthropol. Inst. 82:169-83

Roberts DF. 1978. Climate and Human Variability. Menlo Park, CA: Cummings. 2nd ed.

Rodahl LK. 1952. Basal metabolism of the Eskimos. Fed. Proc. 2:130-37

Rode A, Shephard RJ. 1994. Physiological consequences of acculturation: a 20-year study of fitness in an Inuit community. Eur. 7. Appl. Physiol. 69:516-24

Rode A, Shephard RJ. 1995a. Basal metabolic rate of Inuit. Am. F. Hum. Biol. 7:723-29

Rode A, Shephard RJ. 1995b. Modernization of lifestyle, body fat content, and body fat distribution: a comparison of Igloolik Inuit and Volochanka nGanasan. Int. F. Obes. 19:709-16

Rode A, Shephard RJ, Vloshinsky PE, Kuksis A. 1995. Plasma fatty acid profiles of Canadian Inuit and Siberian Ganasan. Arct. Med. Res. 54:10-20

Ruff CB. 1991. Climate and body shape in human evolution. 7. Hum. Evol. 21:81-105

Ruiz-Pesini E, Mishmar D, Brandon M, Procaccio V, Wallace DC. 2004. Effects of purifying and adaptive selection on regional variation in human mtDNA. Science 303:223-26

Salijukov VB, Lemza SV, Kucher AN, Puzyrev VP. 1992. The role of hereditary factors in phenotypic variability of hormone levels in the population genetically adapted to circumpolar environment. Arct. Med. Res. 51:143-49

Schofield WN. 1985. Predicting basal metabolic rate, new standards and a review of previous work. Hum. Nutr. Clin. Nutr. 39C(Suppl. 1):5-41

Scott EM, Griffith IV, Hoskins DD, Whaley RD. 1958. Serum cholesterol levels and blood pressure of Alaskan Eskimo men. Lancet 2:667-68

Shephard RJ, Rode A. 1996. Health Consequences of "Modernization": Evidence from Circumpolar Peoples. Cambridge: Cambridge Univ. Press

Shetty PS, Henry CJK, Black AE, Prentice AM. 1996. Energy requirements of adults: an update on basal metabolic rates (BMRs) and physical activity levels (PALs). Eur. F. Clin. Nutr. 50:S11-23

Shkolnikov VM, McKee M, Leon DA. 2001. Changes in life expectancy in Russia in the mid1990s. Lancet 357:917-21 
Slezkine Y. 1994. Arctic Mirrors: Russia and the Small Peoples of the North. Ithaca: Cornell Univ. Press

Smals AGH, Ross HA, Kloppenborg PWC. 1977. Seasonal variation in serum T3 and T4 levels in man. F. Clin. Endocrinol. Metab. 44:998-1001

Snodgrass JJ. 2004. Energetics, health, and economic modernization in the Yakut (Sakha) of Siberia: a biocultural perspective on lifestyle change in a circumpolar population. $\mathrm{PhD}$ thesis. Northwest. Univ. 523 pp.

Snodgrass JJ, Leonard WR, Tarskaia LA, Alekseev VP, Krivoshapkin VG. 2005. Basal metabolic rate in the Yakut (Sakha) of Siberia. Am. F. Hum. Biol. 17:155-72

Soares MJ, Sheela ML, Kurpad AV, Kukarni RN, Shetty PS. 1989. The influence of different methods on basal metabolic rate measurements in human subjects. Am. F. Clin. Nutr. 50:731-36

Sorensen MV. 2003. Social and biological determinants of cardiovascular risk among rural and urban Yakut: Impact of socioeconomic upheaval. PhD thesis. Northwest. Univ. 286 pp.

Sorensen MV, Leonard WR, Spencer GJ, Spitsyn VA, Shenin VA. 1999. Correlates of variation in basal metabolism of the Buryat of South Siberia. Am. 7. Hum. Biol. 11:172 (Abstr.)

Sorensen MV, Snodgress JJ, Leonard WR, Tarskaia LA, Ivanov KI, Krivoshapkin VG. 2005. Health consequences of post socialist transition: dietary and lifestyle determinants of plasma lipids in Yakutia. Am. F. Hum. Biol. 17: In press

Sorensen MV, Spitsyn VA, Tarskaya LA. 2000. Health effects of political and economic transition on indigenous Siberian populations. Am. F. Hum. Biol. 12:269 (Abstr.)

Sparti A, DeLany JP, de la Bretonne JA, Sander GE, Bray GA. 1997. Relationship between resting metabolic rate and the composition of the fat-free mass. Metabolism 46:1225-30

Tkachev AV, Ramenskaya EB, Bojko JR. 1991. Dynamics of hormone and metabolic state in polar inhabitants depend on daylight duration. Arct. Med. Res. 50 (Suppl. 6):152-55

Tokarev SA, Gurvich IS. 1964. The Yakut. In The Peoples of Siberia, ed. MG Levin, LP Potapov, pp. 243-304. Chicago: Univ. Chicago Press

World Climate. 2005. World climate: weather, rainfall, and temperature data. http://www. worldclimate.com/

Young TK, Nikitin YP, Shubnikov EV, Astakhova TI, Moffat MEK, O’Neil JD. 1995. Plasma lipids in two indigenous arctic populations with low risk for cardiovascular diseases. $\mathrm{Am}$. 7. Hum. Biol. 7:223-36 
a) males

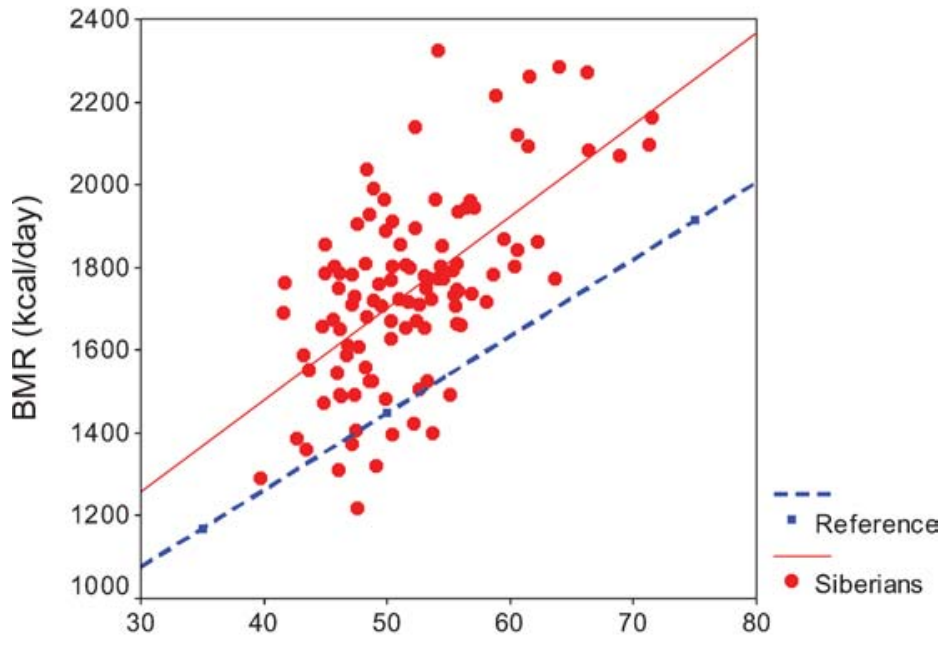

Fat-free mass $(\mathrm{kg})$

b) females

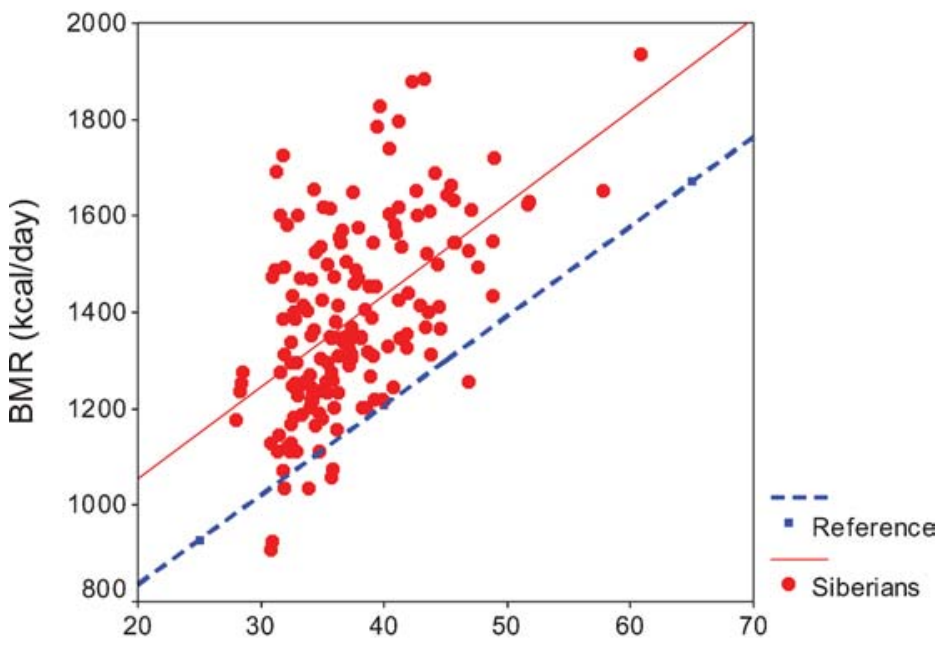

Fat-free mass $(\mathrm{kg})$

Figure 2

Relationship between basal metabolic rate ( $\mathrm{kcal} /$ day) and fat-free mass $(\mathrm{kg})$ in indigenous Siberian $(a)$ men and $(b)$ women compared to estimated values from reference equations of Poehlman \& Toth (1995). BMRs of Siberian men average $16.4 \%(250 \mathrm{kcal})$ higher than predicted values. Siberian women average $18.1 \%$ (220 kcal) higher. 


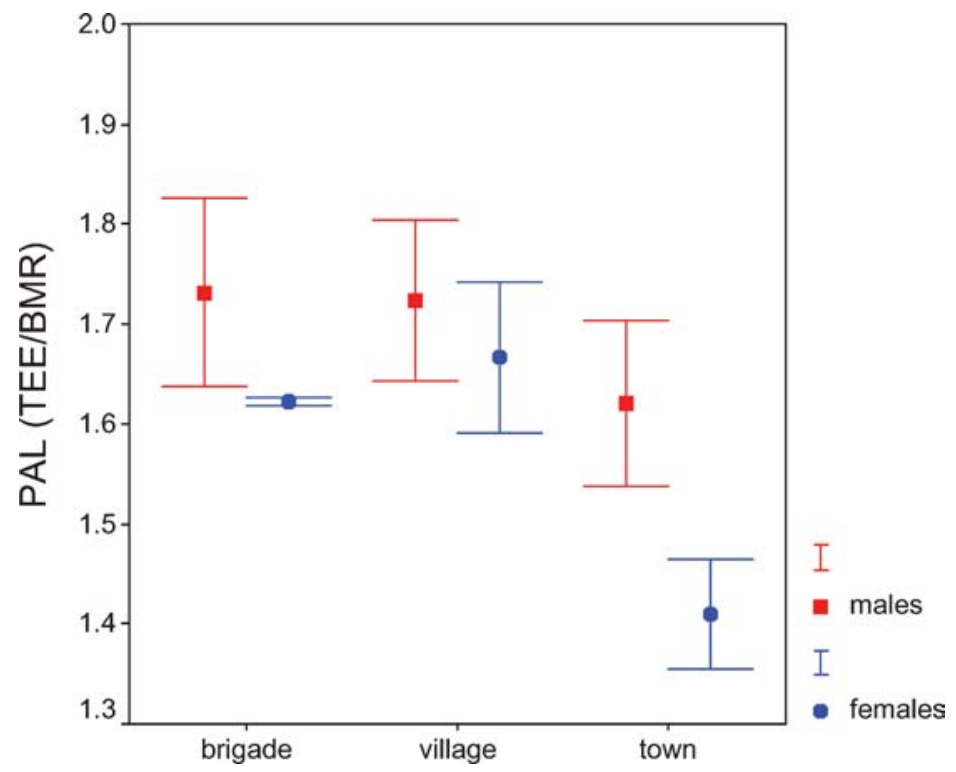

Figure 3

Mean ( \pm SEM) physical activity levels (TEE/BMR) of indigenous Siberian men and women living in different size communities. Town-dwelling women have significantly lower $(\mathrm{P}<0.05)$ daily activity levels than women living in either the herding brigades or small villages. Men show more modest declines in activity levels with urbanization. 
a) males

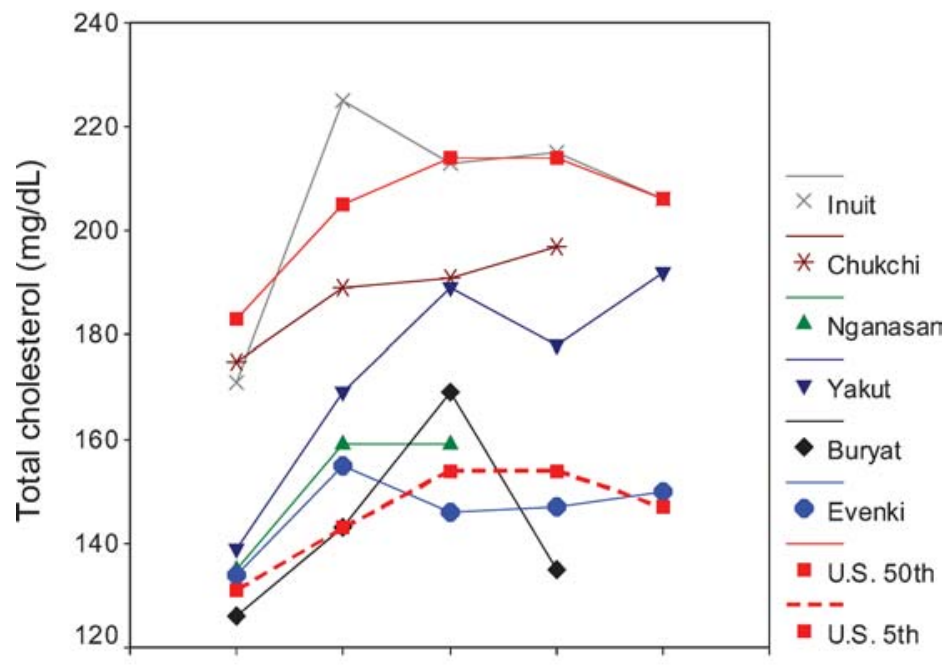

$18-34 \quad 35-44 \quad 45-54 \quad 55-64 \quad 65+$

b) females

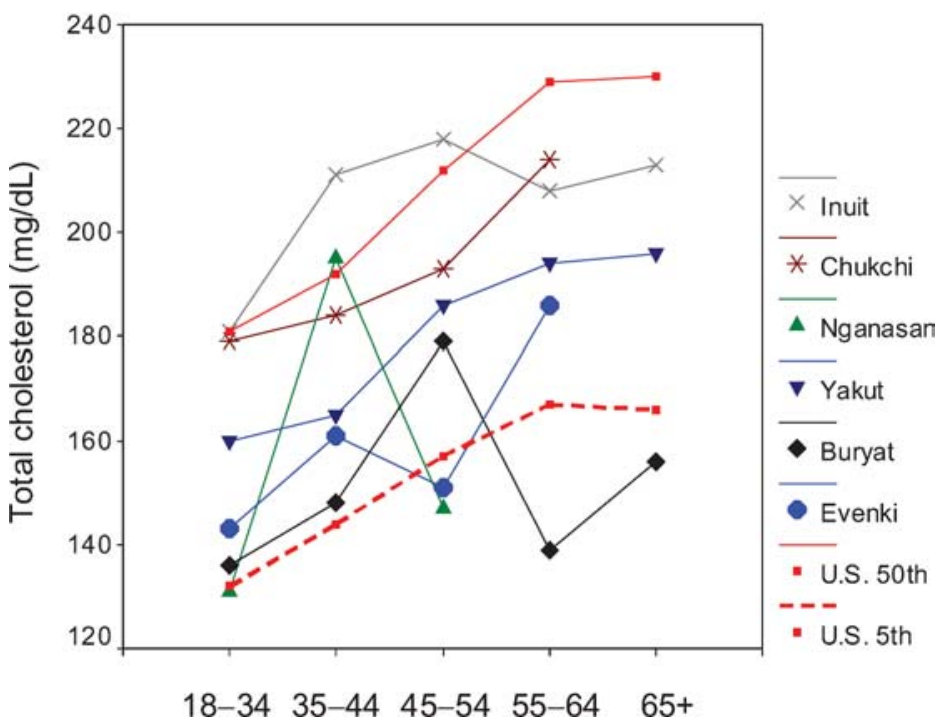

Figure 4

Total cholesterol levels by age group for $(a)$ men and $(b)$ women of 6 indigenous arctic populations (Buryat, Chukchi, Evenki, Inuit, Nganasan, and Yakut) compared to the U.S. 5th and 50th centiles. 
Frontispiece

Sally Falk Moore xvi

\section{Prefatory Chapter}

Comparisons: Possible and Impossible

Sally Falk Moore 1

\section{Archaeology}

Archaeology, Ecological History, and Conservation

Frances M. Hayashida

Archaeology of the Body

Rosemary A. Foyce

Looting and the World's Archaeological Heritage: The Inadequate

Response

Neil Brodie and Colin Renfrew

Through Wary Eyes: Indigenous Perspectives on Archaeology

foe Watkins

The Archaeology of Black Americans in Recent Times

Mark P. Leone, Cheryl Fanifer LaRoche, and Fennifer 7. Babiarz

\section{Biological Anthropology}

Early Modern Humans

Erik Trinkaus

Metabolic Adaptation in Indigenous Siberian Populations

William R. Leonard, 7. Fosh Snodgrass, and Mark V. Sorensen

The Ecologies of Human Immune Function

Thomas W. McDade 495 


\section{Linguistics and Communicative Practices}

New Directions in Pidgin and Creole Studies

Marlyse Baptista

Pierre Bourdieu and the Practices of Language

William F. Hanks

Areal Linguistics and Mainland Southeast Asia

N.F. Enfield

Communicability, Racial Discourse, and Disease

Charles L. Briggs

Will Indigenous Languages Survive?

Michael Walsh

Linguistic, Cultural, and Biological Diversity

Luisa Maffi 599

\section{International Anthropology and Regional Studies}

Caste and Politics: Identity Over System

Dipankar Gupta

Indigenous Movements in Australia

Francesca Merlan

Indigenous Movements in Latin America, 1992-2004: Controversies,

Ironies, New Directions

Fean E. Fackson and Kay B. Warren

\section{Sociocultural Anthropology}

The Cultural Politics of Body Size

Helen Gremillion

Too Much for Too Few: Problems of Indigenous Land Rights in Latin

America

Anthony Stocks

Intellectuals and Nationalism: Anthropological Engagements

Dominic Boyer and Claudio Lomnitz....

The Effect of Market Economies on the Well-Being of Indigenous

Peoples and on Their Use of Renewable Natural Resources

Ricardo Godoy, Victoria Reyes-García, Elizabeth Byron, William R. Leonard, and Vincent Vadez 
An Excess of Description: Ethnography, Race, and Visual Technologies

Deborah Poole....

Race and Ethnicity in Public Health Research: Models to Explain

Health Disparities

William W. Dressler, Kathryn S. Oths, and Clarence C. Gravlee

Recent Ethnographic Research on North American Indigenous

Peoples

Pauline Turner Strong

The Anthropology of the Beginnings and Ends of Life

Sharon R. Kaufman and Lynn M. Morgan

Immigrant Racialization and the New Savage Slot: Race, Migration, and Immigration in the New Europe

Paul A. Silverstein

Autochthony: Local or Global? New Modes in the Struggle over

Citizenship and Belonging in Africa and Europe

Bambi Ceuppens and Peter Geschiere....

Caste and Politics: Identity Over System

Dipankar Gupta

The Evolution of Human Physical Attractiveness

Steven W. Gangestad and Glenn 7. Scheyd

Mapping Indigenous Lands

Mac Chapin, Zachary Lamb, and Bill Threlkeld

Human Rights, Biomedical Science, and Infectious Diseases Among

South American Indigenous Groups

A. Magdalena Hurtado, Carol A. Lambourne, Paul fames, Kim Hill,

Karen Cheman, and Keely Baca

Interrogating Racism: Toward an Antiracist Anthropology

Leith Mullings

Enhancement Technologies and the Body

Linda F. Hogle

Social and Cultural Policies Toward Indigenous Peoples: Perspectives

from Latin America

Guillermo de la Peña

Surfacing the Body Interior

fanelle S. Taylor 


\section{Theme 1: Race and Racism}

Race and Ethnicity in Public Health Research: Models to Explain Health Disparities

William W. Dressler, Kathryn S. Oths, and Clarence C. Gravlee

Communicability, Racial Discourse, and Disease

Charles L. Briggs

Immigrant Racialization and the New Savage Slot: Race, Migration, and Immigration in the New Europe

Paul A. Silverstein

The Archaeology of Black Americans in Recent Times

Mark P. Leone, Cheryl Fanifer LaRoche, and Fennifer F. Babiarz

Interrogating Racism: Toward an Antiracist Anthropology

Leith Mullings ....

\section{Theme 2: Indigenous Peoples}

The Effect of Market Economies on the Well-Being of Indigenous

Peoples and on Their Use of Renewable Natural Resources

Ricardo Godoy, Victoria Reyes-García, Elizabeth Byron, William R. Leonard, and Vincent Vadez

Recent Ethnographic Research on North American Indigenous

Peoples

Pauline Turner Strong

Will Indigenous Languages Survive?

Michael Walsh

Autochthony: Local or Global? New Modes in the Struggle over

Citizenship and Belonging in Africa and Europe

Bambi Ceuppens and Peter Geschiere....

Through Wary Eyes: Indigenous Perspectives on Archaeology

foe Watkins

Metabolic Adaptation in Indigenous Siberian Populations

William R. Leonard, 7. Fosh Snodgrass, and Mark V. Sorensen

Indigenous Movements in Australia

Francesca Merlan

Indigenous Movements in Latin America, 1992-2004: Controversies,

Ironies, New Directions

Fean E. Fackson and Kay B. Warren 
Linguistic, Cultural, and Biological Diversity

Luisa Maffi 599

Human Rights, Biomedical Science, and Infectious Diseases Among South American Indigenous Groups A. Magdalena Hurtado, Carol A. Lambourne, Paul Fames, Kim Hill, Karen Cheman, and Keely Baca

Social and Cultural Policies Toward Indigenous Peoples: Perspectives from Latin America Guillermo de la Peña

\section{Indexes}

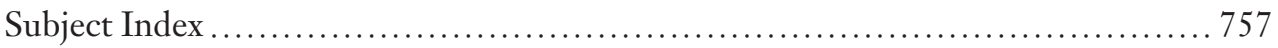

Cumulative Index of Contributing Authors, Volumes 26-34 ................... 771

Cumulative Index of Chapter Titles, Volumes 26-34 ........................... 774

\section{Errata}

An online log of corrections to Annual Review of Anthropology chapters may be found at http://anthro.annualreviews.org/errata.shtml 